\title{
Investment-based Analysis of IT-enabled Business Process Reengineering:
}

\section{A Case Study within Engineering Data Management}

\author{
Theo J.W. Renkema \& Tom Dolan
}

Department of Information and Technology

Graduate School of Industrial Engineering and Management Science Eindhoven University of Technology

The Netherlands

tellfax+31-40-472290/451275

tre@bdk.tue.nl; or tdl@bdk.tue.nl

\begin{abstract}
IT investments are being increasingly undertaken as part of larger business process reengineering (BPR) exercises. The reported failure rates of such BPR projects are typically high. Effective management of the associated investment decision is, therefore, even more important for the success of the project and the business itself. A framework for the evaluation of such investments is presented, which extends existing appraisal techniques to account for important organisational factors. An industrial case study concerning the introduction of an Engineering Data Management (EDM) system is presented and analysed in terms of this framework. It is shown that the framework is amenable to the structuring of such an investment decision. The paper concludes with some recommendations for future extensions to the research.
\end{abstract}

Keywords

Business Process Reengineering, IT investments, Investment evaluation, Engineering Data Management (EDM) 


\section{INTRODUCTION}

Business Process Reengineering (BPR) has emerged as an influential theme in the industrial engineering and information systems disciplines. Many organisations are embarking on BPR initiatives or have an interest in doing so. Recent surveys show for instance, that around $60 \%$ to $70 \%$ of the responding organisations are already involved in BPR programs (Klein, 1993; Butler 1994). The reported failure rates of such BPR projects are, however, typically high. Hammer and Champy (1993) estimate that up to 70\% of BPR projects fail. Belmonte and Murray (1993) state that 'statistics show that less than 45\% of companies that try business process redesign are successful at achieving their intended goals'. The situation that many firms face is perhaps best expressed by Douglass (1993) when arguing that 'Business reengineering is a long, expensive process; most organisations underestimate the time and cost involved. But the payoffs can be staggering. In fact, reengineering may mean the difference between survival and extinction down the road.'

This paper contends that a more rigorous investment-based analysis of IT-enabled BPR projects will provide one step forward in ensuring that BPR delivers value for money. A framework for the analysis and management of BPR-investment evaluation is proposed and applied in the analysis of a case study in Engineering Data Management (EDM). The paper is structured as follows. Section 2 introduces and delineates the concept BPR, and provides our view of a BPR investment as a specific type of IT investment. The third section then goes on to sketch the problems and methods in evaluating IT investments. Building on these two sections, the fourth section proposes a framework for investment-based analysis of BPR. This framework is then applied in a case study of EDM in section 5. The final section concludes with an assessment of the expected contribution of the proposed framework and some future directions of research in the realm of investment-based analysis of BPR projects.

\section{BUSINESS PROCESS REENGINEERING AND BPR INVESTMENTS}

\subsection{BPR: its content and dimensions}

There is little agreement in the literature of what BPR exactly is or should be. Even the name it is given differs from author to author. BPR has, for instance, also been called Business Engineering (Meel et al. 1994), Process Innovation (Davenport 1993) and Core Process Redesign (Kaplan and Murdock 1991). Grover et al. (1993) identify several common elements in the numerous definitions which are typical characteristics of BPR:

- The radical redesign of business processes;

- The typical employment of IT as an enabler;

- The attempts to achieve organisational level strategic outcomes.

In order to get more in-depth insight into the characteristics of different BPR approaches, Jones (1994) distinguishes between five dimensions of BPR (summarised in Table 1), based on: 
The scope of the main processes (the organisational level of the analysis focus);

The scale of change (incremental or radical);

The means of achieving change (systematic or inspirational);

$\square$ The source of the change model (the underlying concepts of the approach);

$\square$ The role of IT (the contribution of IT)

\begin{tabular}{||l||l|l|l|l|l||}
\hline Author & $\begin{array}{l}\text { Scope of } \\
\text { main } \\
\text { processes }\end{array}$ & $\begin{array}{l}\text { Scale of } \\
\text { change }\end{array}$ & $\begin{array}{l}\text { Means of } \\
\text { achieving } \\
\text { change }\end{array}$ & $\begin{array}{l}\text { Source of } \\
\text { change model }\end{array}$ & Role of IT \\
\hline Hammer & Organisation & Radical & Inspiration & Novel & $\begin{array}{l}\text { Essential } \\
\text { enabler }\end{array}$ \\
\hline $\begin{array}{l}\text { Davenport and } \\
\text { Short }\end{array}$ & $\begin{array}{l}\text { Organisation } \\
\text { /dept./task }\end{array}$ & Incremental & Systematic & $\begin{array}{l}\text { Industrial } \\
\text { Engineering }\end{array}$ & $\begin{array}{l}\text { Recursive } \\
\text { relationship }\end{array}$ \\
\hline Harrington & $\begin{array}{l}\text { Department/ } \\
\text { task }\end{array}$ & Incremental & Systematic & Kaizen & $\begin{array}{l}\text { Automation } \\
\text { (secondary }\end{array}$ \\
\hline $\begin{array}{l}\text { Kaplan and } \\
\text { Murdock }\end{array}$ & Organisation & Radical & Systematic & TQM & Key enabler \\
\hline $\begin{array}{l}\text { Business } \\
\text { Intelligence }\end{array}$ & $\begin{array}{l}\text { Department/ } \\
\text { task }\end{array}$ & Incremental & Systematic & Kaizen & $\begin{array}{l}\text { In theory, not } \\
\text { necessary }\end{array}$ \\
\hline Davenport & Organisation & Radical & Systematic & $\begin{array}{l}\text { TQM + IE + 3 } \\
\text { others }\end{array}$ & $\begin{array}{l}\text { Primary } \\
\text { enabler }\end{array}$ \\
\hline Johannson et al. & Organisation & Radical & Systematic & TQM & $\begin{array}{l}\text { One of several } \\
\text { 'Break-Points' }\end{array}$ \\
\hline $\begin{array}{l}\text { Morris and } \\
\text { Brandon }\end{array}$ & $\begin{array}{l}\text { Organisation } \\
\text { /dept./task }\end{array}$ & Incremental & Systematic & $\begin{array}{l}\text { Industrial } \\
\text { Engineering }\end{array}$ & $\begin{array}{l}\text { Not } \\
\text { necessarily } \\
\text { based on IT }\end{array}$ \\
\hline
\end{tabular}

Table 1: Characteristics of different BPR approaches (taken from Jones 1994)

\subsection{What is a BPR investment?}

From the latter section it can be concluded that the currently available BPR approaches still exhibit a large variety on several dimensions. Essential common elements however emerge in the proposed approaches. These common elements provide the foundation on which this paper's view of a BPR investment is based. 
A BPR investment is regarded as a long-term commitment of organisational resources in order to achieve ambitious business goals through (radical or incremental) transformation of business processes with IT as an enabling technology.

As such we see a BPR investment as a specific type of IT investment. Traditionally, IT investments were used to simply automate existing business processes, in order to increase efficiency by internal cost savings and cost avoidance ('automating IT investments'). A BPR investment however stresses the recursive relationship between IT and business processes (see Figure 1) with ambitious business goals in order to improve organisational effectiveness and to gain competitive advantage ('transformating IT investments') ${ }^{1}$.

\section{How can IT support business processes?}

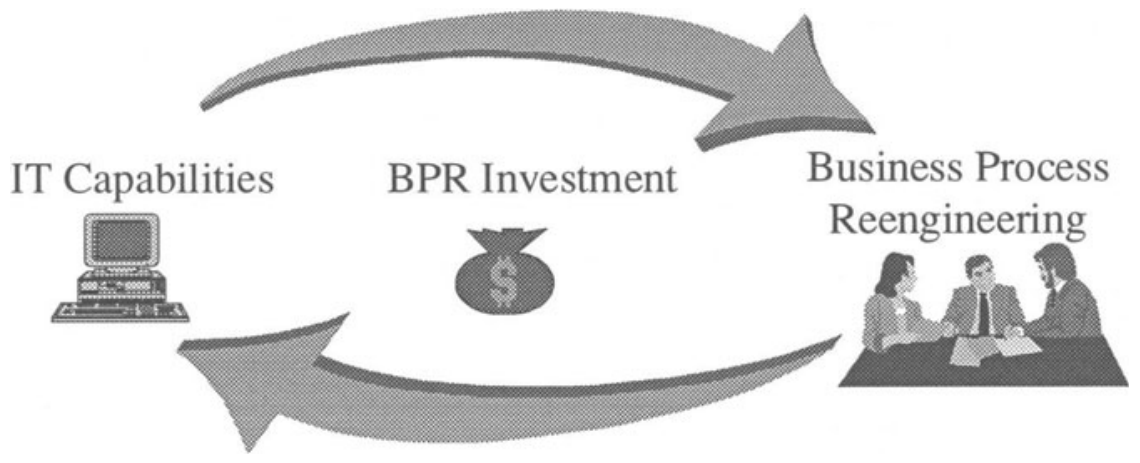

How can business processes be transformed using IT?

Figure 1: BPR investments and the recursive relationship between IT and business processes (adapted from Davenport and Short, 1993)

\section{EVALUATING AND MANAGING IT INVESTMENTS}

\subsection{IT investment evaluation in organisations}

Our view of BPR as a 'transformating' type of IT investment allows us to use existing insights and theories with respect to the evaluation of IT investments. Evaluation of IT investments is not a new problem area in the information systems discipline. Already in 1961 the IFIP devoted

IT investments aimed at the automation of existing business processes can also yield benefits beyond efficiency. Improved efficiency is, however, the initially expressed aim of these investments. 
its first conference to evaluation issues (Frielink, 1961) and in 1968 Joslin wrote his book on computer selection (Joslin, 1968).

The evaluation and management of IT investments has, however, gained the renewed interest of both management and academics. Throughout the last thirty years, IT has come to play a central role in organisations and consequently the sums of money invested in IT have increased considerably. It is estimated that large organizations spend up to $50 \%$ of their annual capital expenditures on IT (Farbey et al., 1993). Senior management are, therefore, unreceptive towards 'act of faith' investment decisions, and seek more robust evidence for the costeffectiveness of proposed investments. Several empirical studies of IT investment decision making practices have recently been conducted, (e.g. Farbey et al. 1993; Willcocks and Lester, 1993). These studies indicate that although many organizations have formal finance-based justification procedures in place, actual decision-making practice is often unstructured and of an ad-hoc character. Also the many non-financial methods for IT evaluation do not seem to be employed in decision-making practice.

\section{INVESTMENT-BASED ANALYSIS OF BPR}

This section proposes a framework for the analysis and evaluation of IT-driven BPR investments that draws on and extends existing methods. The framework is grounded on our contention that the ultimate aim of any BPR investment evaluation is to improve and facilitate decision-making on BPR investments. This has lead us to believe that we need an explicit view of BPR investment evaluation as a decision-making and largely communicative process. To develop this view a model of BPR investment evaluation was designed. Four aspects are distinguished that can all four be used to improve the investment evaluation and to manage the underlying decision-making process. Figure 3 summarises the four aspects, while the remainder of the section elaborates them further.

\subsection{The product of the BPR investment evaluation}

At the heart of the framework lies the product of the investment evaluation, i.e. the set of arguments (evaluation or decision criteria) on the basis of which the decision whether to invest or not is made. Every investment decision is made against the background and judgement of advantages, disadvantages and risks. It is best to make these as explicit and debatable as possible. These investment arguments can either be financial or non-financial advantages and disadvantages, in addition to possible risks involved (see table 2). These arguments also offer a language to communicate the implications of the investment and to increase commitment to the decision made.

The many existing methods for IT investment evaluation (see section 3) focus on the product dimension of investment decision-making in order to arrive at a 'go/no-go' decision. Generally they prescribe a rigid set of investment arguments, without proper recognition of the many local business goals and priorities in an organisation. Table 2 provides a more general structure for a set of investment arguments. It can be used to derive locally based evaluation criteria, using the methods for IT investment evaluation as an input. These criteria can then be graphically presented to the different stakeholders in the evaluation by means of a multi- 
criteria, ratio or portfolio approach. A further treatment of this process is given by (Kusters and Renkema 1994)

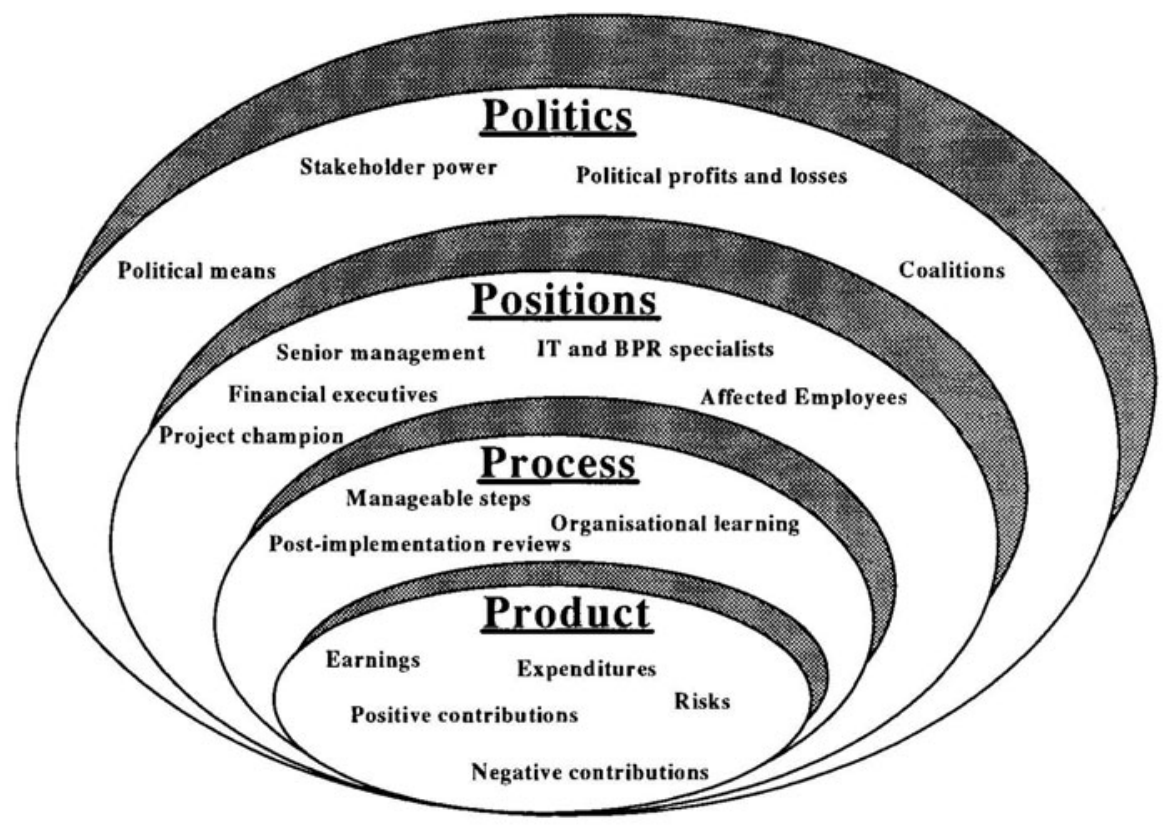

Figure 2: Framework for BPR investment evaluation.

\begin{tabular}{||l|l|l|l||}
\hline Arguments & Positive & Negative & Risks \\
\hline Financial & $\begin{array}{l}\text { Earnings: } \\
- \text { unique } \\
\text { - recurring }\end{array}$ & $\begin{array}{l}\text { Expenditures: } \\
- \text { internal } \\
- \text { external }\end{array}$ & $\begin{array}{l}\text { Cost of capital } \\
\text { Hurdle rate }\end{array}$ \\
\hline Non-financial & $\begin{array}{l}\text { Positive } \\
\text { contribution }\end{array}$ & $\begin{array}{l}\text { Negative } \\
\text { contribution }\end{array}$ & $\begin{array}{l}\text { Development risks } \\
\text { External risks }\end{array}$ \\
\hline
\end{tabular}

Table 2: The product of the investment evaluation (adapted from Kusters and Renkema, 1994)

\subsection{The process of the BPR investment evaluation}

The second aspect of the framework shown in Figure 2 refers to the process of the BPR investment evaluation. This process considers the different phases the evaluation goes through; 
both prior to, and during, project execution. Important recommendations for decision support lie in:

Decomposing investment decision-making into manageable steps, analogous to well known decision-making models (Harrisson 1987):

- problem statement, formulation of project goals;

- evaluation of alternatives;

- choice of investment alternative;

- implementation of the chosen solution.

This subdivision of steps is not meant as a linear and rigid procedure, but more as a pattern of thought, with possible loops.

$\square$ Performing post-implementation reviews of the investment decision to monitor and control the investment across its life cycle. These reviews provide valuable information on whether the investment actually delivers value for money and to what extent there is still room for improvement. These post-implementation reviews can also be used to establish an investment climate in which organisational learning is encouraged. Many investment decisions are made by 'jumping from one project to the other'. Explicit knowledge of prior investments and their realised value can very much contribute to improved decision-making. Regular reviews of the investment also minimise the phenomenon of 'investment entrapment' (Dinther, 1993); a situation in which ever-greater resource commitments are made because of too much emotional involvement, without sound evaluations of increased investments.

\subsection{The positions of the different BPR project stakeholders}

The third aspect that receives special attention in Figure 3 concerns the positions of the different BPR project-evaluation stakeholders. It is advisable to involve all appropriate people in decision-making with respect to the BPR investment. These include:

\section{Senior management}

As discussed in section 2.2, BPR investments are aimed at achieving ambitious business goals. Such goals cannot and should-not be striven for without the support of senior management.

$\square$ IT and BPR specialists

BPR investments are highly dependent on the expertise of specialists in the field of IT in general, and in the field of BPR in particular. Many BPR projects are, in fact, initiated by the IT department (Douglass 1993).

$\square$ Financial executives

Although BPR initiatives have many consequences that cannot easily be expressed in financial terms, it is worthwhile to attempt the estimation of financial consequences as accurately as possible. Financial executives typically have experience in this area, and in addition their analytical rigor can also be used for the estimation of non-financial consequences and for risk analysis.

$\square$ Employees whose work processes are reengineered

Every BPR investment is aimed at the reengineering of some work process, which may often be performed by highly professional employees. Their knowledge of the candidate processes is 
indispensable in deciding what the precise consequences and risks of the BPR project are. Also, their commitment to performing the reengineered work is a prerequisite for achieving value for money from BPR.

$\square$ Project champion

It has been shown (see e.g. Farbey et al., 1993) that the likelihood of success of investment projects is considerably improved when there is a 'project champion' involved. This championship refers to the special effort that is made by some involved stakeholder to make the BPR effort a success. This stakeholder does not necessarily have a formal role that implies such an effort. The more powerful this champion's position in the organisation is the better.

\subsection{The politics of the BPR project}

The previously discussed aspects of the framework sketched a homogeneous, rational picture of an organisation. This view implies for instance that the different stakeholders in the investment evaluation share the same intentions, goals and priorities (in terms of Lammers (1983) the 'system model'). A more realistic view is that of an organisation in which different stakeholder groups have their own wishes and preferences (the 'coalition model'; Lammers, 1983). Such a view allows for the recognition of conflicting interests and the use of political means to safeguards one's interests (Peffer, 1981; Mintzberg, 1983).

Decision support with respect to the politics of the BPR evaluation lies in what has been called 'stakeholder analysis'. Boonstra (1991) suggests the following steps in such an analysis:

1. Listing of stakeholders, their estimated power and impacts of the proposed investment;

2. Assessment of possible 'winners' and 'losers' and their possible (political) 'profits' and 'losses';

3. Establishment of feasible strategies (e.g. financial compensation) to influence the political account of profits and losses.

\section{THE INDUSTRIAL CASE STUDY}

We have applied the investment framework described above to a real-life industrial project (an Engineering Data Management project) in order to:

- verify its applicability in an industrial context;

- investigate limitations which will become the subject of further research.

Engineering Data Management (EDM) was chosen as it represents a typically industrial, largescale, IT investment which has possibilities to not only automate, but also transform the underlying business process. These possibilities exist because EDM provides an organisationwide communications infrastructure. The infrastructure is not enough, however, to ensure improved development and production, that requires complementary process reengineering.

EDM implementation entails formalism (of procedures) and structure (of documents). It demands that previously ad hoc work practices must be examined and perhaps re-designed, that informal codes of behaviour regarding documentation must be analysed and modified to 
fully avail of the EDM functionality. This close relationship between IT and the underlying process to be supported is critical to the successful implementation of EDM (or indeed any major IT investment). It is widely accepted that the most serious barriers to successful IT implementation are not technological but organisational in nature (Scott Morton, 1991) and any serious IT/BPR project should account for this fact.

Unless the entire development process is re-examined in the light of the new possibilities, and unless management and users are committed to re-engineering those processes which hinder optimal IT exploitation; the project will fail. Similarly, the IT product (in this case an EDM System) must support good design in all its organisational aspects, in an integrated way.

This realisation is the cornerstone of IT-enabled BPR, and also of the investment appraisal framework presented in this paper, which regards the IT investment from both a technical and organisational perspective. These themes will be expanded in the case description which follows in section 5.2, after a brief description of the case-study site.

\subsection{Introduction to the site:}

The site for the case in the headquarters of a world-wide manufacturer of high technology medical diagnostic equipment employing 10000 people. The site is the main centre for both design and manufacturing, and the development organisation is composed of business units ${ }^{2}$ related to major technical application areas. The company has a waterfall-based development model (see Figure 3), supported by a manual documentation system for project management and review.

\begin{tabular}{c|c|c|c|c|c|c}
\multicolumn{2}{c}{ phase 1 } & phase 2 & \multicolumn{2}{c}{ phase 3 } & phase 4 & phase 5 \\
\hline Feasibility & $\begin{array}{c}\text { Overall } \\
\text { Design }\end{array}$ & Detail Design & $\begin{array}{c}\text { Integration - } \\
\text { Test }\end{array}$ & $\begin{array}{c}\text { Start } \\
\text { Production }\end{array}$ & \\
\hline
\end{tabular}

Figure 3: the phases in the product development process

This company is the leader in the highest end of the market, but recognises that the industry is entering a very dynamic period and wants to prepare its development activities to meet the competitive demands. In particular; timing and costs will become much more critical as success factors, as will the provision of software to support the entire application environment. These pressures are resulting in a development process which must deliver a more complex product in a shorter timescale, this was the impetus for the EDM investment. It is also worth noting that one of the 'selling points' of the project was the fact that EDM would enable an improved development process (there were even estimated cost savings presented). In fact the view held by the project proposers (the IT department) was that EDM was an infrastructure product which would facilitate the re-design of the development process (i.e. IT-induced BPR) to improve productivity.

2 They are not business units in the strict sense as sales responsibility is held at regional level. 


\subsection{Applying the framework to the EDM case study}

The aim of this paper is to investigate the suitability of the evaluation framework described, to an industrial, BPR scenario. To do this we have taken a current EDM implementation project; investigated the evaluation process; and structured it in the context of the framework (the four P's).

\section{The product of the BPR investment evaluation}

As discussed in section 4.1, the product of the investment evaluation refers the 'go/no-go' decision and the set of investment arguments that is used to arrive at this decision. This EDM investment project was justified on the need to improve the product development process in order to meet increased competitive demands. Improvement in this respect lies in delivering a more complex product in a shorter timescale, against lower costs. The more efficient management of product and process data was regarded an important prerequisite for this. One of the important 'selling points' of the EDM project was that it would enable an improved development process, where improvement was particularly visible in the estimated cost savings. EDM was considered an infrastructure product which would facilitate the redesign of the development process.

The estimated cost savings were projected in the report of a large industrial consultancy firm, commissioned to assess the feasibility of implementing the EDM system. These consultants organised a workshop with several developers, which investigated current practice and identified the core problems with the development process. Estimates were made of the cost savings possible from the removal of these problems by EDM, and these cost savings outweighed the financial expenditures considerably. As such, the report sketched a picture of an investment with only limited risks. The more qualitative, strategic benefits emerged later on in the investment evaluation.

There was also the choice of the software package in order to be able to implement the proposed EDM system. A 'buyers guide' of available EDM software packages (which was commercially available) was used the get an initial idea of the available packages. The choices between the three final candidates (two external packages, one package developed by a sister company) was made on the basis of functional and technical requirement and intuitions concerning the packages.

\section{$\square$ The process of the BPR investment evaluation}

As with many BPR projects, the EDM investment idea was launched from the IT department. The department foresaw major advantages in the use of a uniform EDM software tool. Internal triggers within the IT department were the limited capacity of the existing data-management tools and their lack of uniformity. Several years before, a comparable investment initiative was proposed by the IT department. This project was far from successful. Perceived causes for this lie in: technological immaturity, organisational immaturity and the fact that the then proposed system was installed on a mainframe computing environment. This centralised structure highly contrasted with the professional, autonomous, working environment of the product developers. 
The IT department put great effort into 'selling' the investment idea to development and management. The projected improvements in the development process gradually turned their efforts into a success. The management team established an investment budget and decided to install a 'study committee' to investigate the possibilities of EDM implementation. This committee contracted a large industrial consultancy firm to explore the feasibility of EDM. In the light of the consultants' findings, the committee then proposed to invest in the system and management decided to go ahead with the EDM investment. A project committee was installed to guide the implementation of the system. It was also decided to implement the system gradually, through pilot projects. At this early stage of the project, no post-implementation of the investment decision has taken place.

\section{The positions of the BPR investment evaluation stakeholders}

The IT department played a central role throughout the investment decision-making process. It proposed the EDM investment, and its expertise was used in the continuation of the investment. The support and attention of the management team was also seen as an important factor. One member of this team put a lot of personal effort into the success of the EDM project. He is seen as a good candidate for the title 'project champion'. The study committee consisted of representatives from the several involved departments. This committee collaborated with the aforementioned consultancy firm. The project committee that is responsible for the ongoing system implementation phase comprises a representative of the IT department, the engineering department and product development. This committee has also consulted another plant of the case study organisation (in Germany) to ensure uniformity in their respective approaches to EDM.

\section{$\square$ The politics of the BPR investment evaluation}

Several issues can be mentioned that relate to the politics of the investment evaluation. The political atmosphere was very much influenced by the different backgrounds and perceptions of the IT department versus the product developers. This can be regarded as a typical example of the classical conflict between 'IT' and 'users'. Political issues resulted from the rather long distance between the management of the IT department and the management team. Their communication mainly took place via separated hierarchical channels. A final point worth mentioning is that the focus on the justification through cost savings can be traced back to the cost consciousness of the Manufacturing Engineering department in the 'study committee'.

\subsection{Analysis of the case study}

The EDM case raises some diagnostic questions with respects the way BPR investment evaluation was carried out. These can be seen as points for improvement with respect to future BPR initiatives in the case study organisation.

The product of the investment evaluation, i.e. the 'go/no-go' decision and its constituting investment arguments, was chiefly oriented towards projected cost savings. The more strategic, and possibly more essential, investment arguments emerged later on in the evaluation. This concentration on cost savings more or less stood in the way of a well- 
founded and explicitly communicated strategic investment orientation, accounting for both financial and non-financial opportunities, drawbacks and risks.

The process and positions of the BPR investment evaluation were fairly straightforward, including the project committee's and senior management's support (the role of the 'project champion' in the latter group was seen to be very beneficial). An important role was played by an external consultancy firm, who predicted many efficiency gains. The focus of external legitimatisation of the investments might, however, have been inhibiting internal commitment to the decision made. It is not fully clear to what extent organisational stakeholders felt that were the investment would indeed be worthwhile or were told so.

The politics of the investment evaluation reflects the often reported divergence between the work climates of the IT department and end-users. As such, this observation implies that within the case study organisation, room for improvement lies in removing cultural barriers between the two groups. This claim, however, also holds for the information systems discipline in general. A further observation regarding the politics of the investment evaluation is the seemingly over-involvement of the people that were particularly costconsciousness. This fuelled the already cost-driven investment justification, possibly at the cost of the interest of other stakeholders who would benefit most, i.e. the product developers.

\section{CONCLUSION}

IT investments are increasingly undertaken as part of larger BPR exercises. The reported failure rates of BPR programs are however typically high. The management of the associated investment decision has therefore become more important in ensuring that the BPR investment delivers value for money. This paper argued that a more rigorous, investment-based analysis of BPR projects will provide one step forward in achieving this. A framework for the analysis and management of BPR investment evaluation was proposed and used to examine a case study in Engineering Data Management.

It has been shown that the proposed framework can be used to analyse BPR investment evaluation both in terms of the arguments put forward in the course of the decision-making process (the product of the evaluation), as well as other important organisational factors (the process, positions and politics of the evaluation).

The analysis of the case convinces us that the research reported here brings a new and challenging research field to light. The many claims made with respect to the value to be gained from BPR investment highly contrast with the finding that BPR programs are often the subject of disappointed expectations. These expectations can only be judged on their merits if they are debated as part of a well-structured investment evaluation. Important recommendations for future work, therefore, lie in: 
$\square$ Extending the analysis of BPR investments in terms of the proposed framework to other organisational settings and other research. This will ensure that the generic framework is free from the excess influence of local circumstances and the researchers involved. Such analyses give the investing organisation a means to diagnose their current way of managing BPR investment evaluation as a first step towards encouraging organisational learning.

A second and more important recommendations concerns the use of the framework in a more prescriptive, action-oriented manner. For this, more detailed prescriptions on all aspects of the framework should be given. This implies more research on the distinctive characteristics of BPR investment evaluation and the way it is carried out in practice.

\section{REFERENCES}

Belmonte R.W. and Murray J. (1993), Getting ready for strategic change: surviving business process redesign, Information Systems Management, Summer, 23-39

Boonstra, A. (1991), Political aspects of information systems development (in Dutch), Informatie, nr.12, 857-864

Butler, C. (1994), The role of $\mathrm{I} / \mathrm{T}$ in facilitating BPR: observations from the literature, in: Business process re-engineering: information systems opportunities and challenges (Glasson, B.C. eds.),

IFIP TC8, North-Holland, Amsterdam, 147-160.

Checkland P. (1989), Soft systems methodology, in: Rational analysis for a problematic world (Rosenhead J. ed.), John Wiley, Chicester. 71-100.

Davenport, T.E. and Short, J.E. (1990), The new industrial engineering: information technology and business process redesign, Sloan Management Review, Summer, 11-27.

Davenport T.E., (1993), Process innovation: reengineering work trough information technology, Harvard Business School Press, Boston.

Dinther, M. van. (1992), Caught in a web, psychological backgrounds of investment decisions (in Dutch), AXA, Equity and Law.

Douglass, D.P. (ed.) (1993), The role of IT in business reengineering, I/S Analyzer, August, 1-16.

Farbey, B.; Land, F. and Targett, D. (1993), How to assess your IT investment: a study of methods and practice, Butterworth-Heinemann, Oxford.

FinTech (1992), Spotlight: business process reengineeering brings big benefits, FinTech Electronic Office, December 2, 4.

Frielink, A.B. (ed.,) (1961), Auditing Automatic Data Processing, Elsevier, Amsterdam.

Grover, V.; Teng, J.T.C. and Fiedler; K.D. (1993), Information technology enabled business redesign, Omega, nr. 4, 433-447.

Hammer M. and Champy, J. (1993), Reengineering the corporation: a manifesto for business revolution, Nicholas Brealey, London.

Harrington H.J. (1991), Business Process Improvement, McGraw Hill, London.

Harrison, E.F.(1987), The Managerial Decision Making Process, Houghton Mifflin, Boston.

Jones (1994), M., Don't emancipate, exaggerate: rhetoric, reality and reengineering, in: Transforming organizations with information technology (Baskerville, R.; Smithson, S.; Ngwenyama,O.; and DeGross, J.I. eds), IFIP 8.2, North-Holland, Amsterdam, 1994, 357-378.

Joslin, E.O.(1968), Computer selection, London, Addison-Wesley, 1968.

Kaplan, R.B. and Murdock L. (1991), Core process redesign, McKinsey Quarterly, 27-49

Klein, M.M. (1993), IE's fill facilitator role in benchmarking operations to improve performance, Industrial Engineering, September, 40-42 
Kusters, R.J. and Renkema, T.J.W. (1994), Designing local evaluation models for IT investments, in: Proceedings fifth European Software Cost Modelling Conference, (ed. P. Rook), Ivrea (I),

Lammers, C.J. (1983), Comparing Organisations, Spectrum, Utrecht.

Meel, J.W. van; Bots, P.W.G. and Sol, H.G., Towards a research framework for business engineering, in: Business process re-engineering: information systems opportunities and challenges (Glasson, B.C. eds.), IFIP TC8, North-Holland, Amsterdam, 581-592.

Mintzberg, H. (1983), Power in and around organizations, Prentice Hall, Englewood Cliffs.

Morris D. and Brandon J. (1993), Reengineering your business, McGrawHill, London.

Pfeffer, J. (1981), Power in organizations, Pitman, Boston.

Renkema, T.J.W. (1994), Investing in the information technology infrastructure, in: Proceedings Doctoral Consortium of the ICIS, Vancouver Island, University of Victoria, DD 1-13.

Scott Morton, M. (ed.) (1991), The corporation of the 1990's, information technology and organizational transformation, Oxford University Press, Oxford.

Willcocks L. and Lester S. (1993), How do organizations evaluate and control information systems investments? Recent UK survey evidence, In: Human, Organizational, and Social Dimensions of Information Systems Development (Avison D. Kendall J.E. and DeGross J.G. Eds.), IFIP 8.2, North-Holland, Amsterdam, 15-40

\section{BIOGRAPHY}

Theo J. W. Renkema holds a masters degree (1992) in Economics from the University of Groningen, the Netherlands, which he received with the distinction 'cum laude'. He was employed as a research assistant in the Business Economics department of Groningen University ('89 - '92), investigating potential decision support for the organisational diagnosis tasks of interim-managers. Currently he is conducting doctoral research in the Faculty of Industrial Engineering and Management Science, Eindhoven University of Technology. The central theme of this research is the organisational decision-making process and evaluation of investments in the information-infrastructure. The research is conducted in close co-operation with a large financial services organisation.

Tom J. Dolan obtained his primary and masters degrees in Industrial Engineering at University College Galway, Ireland, in 1990 and 1992 respectively. He then worked as a research engineer at the CIM Research Unit in Galway for 2 years, which included a 9 month placement at the Eindhoven University of Technology. In November 1994 he began his doctoral studies in Eindhoven. His current research interests include: requirements management, product data modelling, and design process improvement. His research is being supported by the medical equipment manufacturer referred to in this paper. 